\title{
Spinal kord hasarlı hastanın rehabilitasyonu
}

\author{
Rehabilitation of the patient with spinal cord injury
}

\author{
Berrin Gündüz ${ }^{1}$, Işı| Turna² \\ 'İstanbul Fizik Tedavi Rehabilitasyon Eğitim ve Araştırma Hastanesi, İstanbul \\ ${ }^{2}$ Acıbadem Atakent Hastanesi, İstanbul
}

\begin{abstract}
Spinal kord hasarı kişinin, aile ve yakınlarının yaşamını aniden, tamamen değiştiren kötü bir nörolojik tablodur. Hasar sonrasında birçok nörolojik ve tıbbi sorun ortaya çıkar; hastanın neredeyse tüm vücut fonksiyonları etkilenir. Spinal kord hasarlı bir kişinin rehabilitasyonunda bir yandan kişinin tıbbi durumu stabilize edilmeye çalışılırken, diğer yandan ortaya çıkan veya çıkabilecek komplikasyonlar ile mücadele edilir. Hasta ve ailesi bu süreç ile ilgili bilgilendirilerek, günlük yaşama en iyi şekilde adapte edilmeye çalışılır. Spinal kord hasarı sonrasında sıklıkla karşılaşılan sorunlar hastanın yaralanma seviye ve şiddeti ile ilişkili olarak otonom fonksiyon bozuklukları, pulmoner sorunlar, nörojen mesane ve barsak, seksüel disfonksiyon, bası yarası, derin ven trombozu ve pulmoner emboli, spastisite, ağrı, kas iskelet sistemi ile ilgili heterotopik ossifikasyon, osteoporoz, aşırı kullanım yaralanmaları olarak sıralanabilir. Bu komplikasyonların önlenmesinde erken rehabilitasyonun yeri tartışılmaz çok önemlidir. Rehabilitasyon büyük bir interdisipliner ekip ile hastanede başlayan uzun bir süreçtir. Rehabilite edilen ve uygun hedeflere ulaşılarak taburcu edilen hastalar düzenli olarak kontrol edilmelidir.
\end{abstract}

Anahtar sözcükler: spinal kord hasarı; rehabilitasyon
Spinal cord injury is a severe neurological disease which suddenly and seriously changes the life of the patient and family. Various neurological and medical problems are seen after injury; nearly all the body functions are affected. In the rehabilitation of the patient with spinal cord injury, the medical status is tried to be stabilized while struggling with the present or possible complications. The patient and his family are informed and tried to be adapted to their daily life as best as possible. According to the level and severity, complications frequently encountered after spinal cord injury are: autonomic dysfunctions, pulmonary problems, neurogenic bladder and bowel, sexual dysfunction, pressure ulcer, deep vein thrombosis, pulmonary emboli, musculoskeletal problems like heterotopic ossification, osteoporosis, and overuse injuries. Early rehabilitation is very important in preventing these complications. Rehabilitation is a long process which starts in the hospital with the collaboration of a huge interdisciplinary team. Rehabilitated patients who leave the hospital after the treatment reaching a certain expected level should be followed up at regular intervals.

Key words: spinal cord injury; rehabilitation

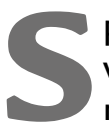
pinal kord hasarı, spinal kord yaralanması veya son yıllarda dilimizde daha sık kullandığımız terminoloji ile omurilik yaralanması (OY), hasta ve hasta yakınları için beklenmedik, ani olarak ortaya çıkan ve genellikle ömür boyu süren bir nörolojik tablodur. Tüm dünyada, kesin veriler olmamakla birlikte, her yıl 250.000-500.000 kişinin OY olduğu tahmin edilmektedir. ${ }^{[1]}$ Türkiye genelinde 2000 yılında yapılmış bir çalışmada, yıllık insidans milyonda 12,7 olarak tahmin edilmekte, ülke çapında kullanılan veri tabanının olmaması nedeni ile çok kesin rakamlara ulaşılamamaktadır. ${ }^{[2]}$ Amerika'da ise yıllık insidans ortalama 17,500 olgudur. ${ }^{[3]}$ Travmatik OY'nin \%70-80 erkeklerde olduğu görülmektedir.[3] Ülkemizde travmatik OY'lerde erkek/kadın oranı 2,5:1, yaralanma yaşı 35,5 olarak bildirilmektedir. ${ }^{[2]}$ Travmatik OY'lerin en sık nedenleri; trafik kazaları (\%40-50), düşme (\%30$40)$, şiddet (\%2-14) ve spordur (\%7). ${ }^{[3,4]}$ Etiyoloji dağılımı toplumlara ve değişik zaman dilimlerine göre farklılık gösterebilmektedir. ${ }^{[5]}$ Travmanın sonucunda önemli psikolojik, fizyolojik ve sosyal problemler yaşanır. Geçmişte OY uzun yıllar tedavi edilemez bir hastalık olarak görülürken 20. yüzyılda tıpta gelişmelere paralel olarak hastaların sağkalım oranları ve yaşam süreleri giderek artmış ve normal toplumun değerlerine yaklaşmıştır. Spinal kord hasarı rehabilitasyonunda

- İletişim adresi: Uzm. Dr. Işıl Turna, Halkalı Merkez Mahallesi, Halkalı Altınşehir İstanbul Cad. No:16, Küçükçekmece, İstanbul Tel: 0530 - 2898782 e-posta: isilturna@gmail.com

- Geliș tarihi: 1 Kasım $2018 \quad$ Kabul tarihi: 1 Kasım 2018 
amaç; fiziksel bağımsızlığı en üst düzeye çıkarmak, yaşam kalitesini arttırarak hastayı üretken ve yaşına uygun sosyal rolleri üstlenen bir birey haline getirmektir. Hastanın beklentilerini ve ulaşılabilecek hedefleri belirlemek, takip ve tedavi motivasyonunu önemli derecede etkiler. Erken rehabilitasyon ile akut komplikasyonların önlenmesi sağlanarak kronik dönemde fonksiyonel kazanımlara ulaşmak kolaylaşır. Rehabilitasyon interdisipliner bir ekip işidir; ekibin lideri fiziyatristtir. Ekibin diğer üyeleri hasta ve ailesi, fizyoterapist, iş uğraşı terapisti, hemşire, sosyal çalışmacı, ortotist, diyetisyen, gerekli durumlarda diğer branşlardan (ortopedist, nöroşirurjiyen, ürolog, plastik cerrah, dahiliye uzmanı, psikiyatrist gibi) uzman hekimlerdir. Ayrıca gerektiğinde solunum terapisti ve konuşma terapisti eklenebilir.

Özel OY ünitelerinde tedavi edilen hastalarda; yaşam oranlarının daha yüksek, komplikasyonların daha nadir, yatış sürelerinin daha kısa ve rehabilitasyon sonuçlarının da daha iyi olduğu bildirilmektedir. ${ }^{[3]}$ OY'li hasta bakımı konusunda eğitimli ve tecrübeli bir ekiple rehabilitasyonun daha yüz güldürücü olması beklenir. Yaralanma sonrası erken rehabilitasyon, kişinin hayata uyumu ve belirlenen hedeflere ulaşılması için çok önemlidir.

\section{FiZiKSEL BECERI EĞiTiMi}

OY'li hastanın kendine bakım, günlük yaşam aktivitesi (GYA) ve mobilite yönünden olabildiğince bağımsız olması hedeflenir. Bunun için eklem hareket açıklı̆ı (EHA) ve güçlendirme egzersiz programı ve ortez verilir. Tamamen bağımsız olmayan hastalara bakıcılardan nasıl güvenli yardım alacağı konusunda eğitim verilmelidir; bu hem bakıcı hem de OY'li hastanın sağlı̆̆ı için önemlidir. ${ }^{[3]}$

Erken dönem rehabilitasyon, öncelikle ikincil komplikasyonları önleme, nöral iyileşmeyi hızlandırma ve yaralanma sonrası fonksiyonu maksimuma çıkarmayı hedefler. Yatak içi pozisyonlama ilk yapılması gerekendir. Hasta yatak dışına çıkmaya hazır olduğunda minder egzersizlerine başlanır. Akut dönemde hastalar tıbbi olarak stabil olmalı ve ihtiyaç duyduğu rehabilitasyon programına, tolere edebileceği yoğunluktaki egzersizlerle başlanmalıdır. ${ }^{[6]}$

Minder aktiviteleri; dönme, yüzüstü dirsek ve eller üzerinde pozisyonlama, uzun oturma, kısa oturma ve transfer eğitimini içerir. Hastaya vücut ağırlığını kolları ile kaldırıp push-up yapması öğretilir. Transfer eğitiminde komplet paraplejik veya alt seviye tetraplejik bir hastada erken dönemde transfer tahtası kullanılabilir. Lezyon seviyesi ve şiddetine göre transfere katkıda bulunamayan hastalarda askılardan yararlanılabilir; alt ekstremitelerinde ekstansör tonusu veya kas fonksiyonu olanlarda, oturur vaziyette veya ayakta pivot transferi yapılabilir. ${ }^{[3]}$

Ayakta durma çalışmaları için ayarlanabilen masa veya ayakta durma bacası kullanılabilir. Erken dönemde ortostatik hipotansiyon, kronik dönemde osteoporoza dikkat edilmelidir. Yapılan çalışmalarda, \%34-75 oranında OY hastasının en az bir kez düştüğü saptanmıştır. ${ }^{[7]}$ Ambulasyon için komplet torakal seviye yaralanmalı hastalarda diz ve ayak bileğini destekleyecek diz - ayak bilek - ayak ortezlerine ihtiyaç vardır. Sadece terapötik ambulasyon yapılacak hastalarda diz eklemini destekleyecek bir posterior-shell ve dorsifleksör bant yeterli olabilir. ${ }^{[3]}$

Yürüme için öncelikle paralel barda ayağa kalkma, dengede durma, ayakta push-up yapma, ayakta dururken dönme, kalça elevasyonuyla alt ekstremitelerin ilerletilmesi, adımlama ve ardından swing-through yürüyüşü çalışılır. Paralel barda rahat yürümeye başladıktan sonra yürüteç (walker), daha sonra koltuk değnekleriyle yürüyüş çalışmaları başlar. ${ }^{[4]}$

Birçok kaynakta seviyelere göre hangi fiziksel becerilerin kazanılabileceği tanımlanmış olsa da (Tablo 1 ), ulaşabilen ambulasyon düzeyleri yaş, cinsiyet, üst ekstremite gücü, vücut ağırlığı, hasta motivasyonu ve sosyal destek durumuna göre kişiden kişiye farklılık göstermektedir. Hastalar için küçük hedefler konulmalı, hasta bunu başardıktan sonra bir sonraki adıma geçilmelidir.

\section{TEKERLEKLI SANDALYE BECERILERi}

Son zamanlarda yapılan çalışmalarda tekerlekli sandalye ile mobilitenin egzersiz programlarının, hastanın ev içi-dışı, sosyal yaşamında beceri kapasitesini \%1825 oranında arttırdığı saptanmıştı. ${ }^{[5]}$ Bu açıdan, hastaya uygun tekerlekli sandalye seçilmeli, etkin ve güvenli tekerlekli sandalye kullanımı için eğitim verilmelidir. Çoğunlukla hastalarda duyu kusuru olduğundan bası yarası yönünden tekerlekli sandalye minderlerine özen gösterilmelidir.

\section{ROBOTIK REHABILITASYON}

Nörorehabilitasyonda hastanın rehabilitasyon sırasında katılım düzeyinin kortikal plastisiteyi arttırdığı bilinmektedir [1]. Son dekadlarda omuriliğin sadece üst merkezlerden gelen emirleri ekstremitelere ileten bir sistem olmadığı, supraspinal kontrol olmadan da yürüme ve ayakta durma sırasındaki karmaşık propriyoseptif girdilerin omurilikte işlendiği saptanmıştır. ${ }^{[3,4]}$ Özellikle inkomplet olgularda, yoğun rehabilitasyon programlarıyla ambulasyon parametrelerinin iyileştirildiğini gösteren çalışmalar vardır. ${ }^{[4]}$ Söz konusu ambulasyon çalışmaları hem hedefe yönelik konvansiyonel 
Tablo 1. Komplet omurilik yaralanma seviyesi ve hedeflenen fonksiyonel durum

- C2-3: Yapay solunum cihazına gereksinim, GYA tam bağımlı

- C4: Dil, çene veya pnömatik kontrollü motorlu TS, GYA'da tam bağımlı

- C5: Özel gereçlerle GYA'yı yapabilir, el kontrollü motorlu TS

- C6: Tenodezis ile elde kavrama vardır, topuz tutamaklı TS, el kumandalı araba

- C7: Transferlerde bağımsız, rampa inme çıkma hariç TS

- C8-T1: GYA, TS bağımsız

- T2-10: Ortez ile ayakta durma ve terapötik ambulasyon

- T11-L2: Uzun bacak yürüme cihazı ve koltuk değneği ile ev içi ambulasyon

- L3-S3: Kısa bacak yürüme cihazı ve önkol değneği ile toplum içi ambulasyon

GYA, günlük yaşam aktiviteleri; TS, tekerlekli sandalye.

rehabilitasyon çalışmaları hem de manuel veya robotik vücut ağırlı̆ının desteklendiği yürüme bandı eğitimleriyle yapılmaktadır. ${ }^{[4]}$ Bu çalışmaların ambulasyon üzerine uzun dönem etkinlikleriyle ilgili kanıta ihtiyaç olsa $\mathrm{da}$, genel sağlık durumu, psikolojik durum ve motivasyon üzerine etkileri de göz ardı edilmemelidir. Son yıllarda ülkemizde de robotik rehabilitasyon ünitelerinin sayısı giderek artmaktadır.

\section{OY ЕĞітімі}

OY hastaların ve ailelerinin hayatlarında kalıcı zorluklar ve değişikliklere neden olur. Hastalarda \%17-25 oranında psikolojik sorunlar oluşur. ${ }^{[8]}$ Özellikle erken dönemde OY'li hasta ve yakınları şaşkın, çaresiz hatta korkmuş durumdadır. Rehabilitasyon başlangıcında iyi bir eğitim verilmesi hem hasta ve yakınlarının bilgi düzeyini arttırır hem de başarılı bir sosyal uyum için kişileri duygusal olarak hazırlar. Hasta böyle bir eğitime birçok kaynaktan ulaşabilse de (internet, sosyal dernekler, diğer hastalar) rehabilitasyon ekibi tarafından kapsamlı bir eğitimin verilmesi hasta ve sağlık çalışanları arasındaki iletişimi olumlu etkileyecektir. ${ }^{[3]}$ Rehabilitasyon sırasında hastanın yaşayacağı çevrede ve evde gerekli düzenlemeler yapılmalıdır. Son yıllarda bazı iyileştirmeler yapılmakla birlikte ülkemizde toplumsal engellerin kaldırılması için kat edilecek uzun bir yol vardır.

\section{MESLEKI EĞіTiM}

OY sonrası işe geri dönme veya iş sahibi olma topluma katılımın en önemli göstergeleri arasındadır. Bu kişiye hem toplumsal bir değer katar hem de ekonomik bağımsızlığına olanak verir. OY sonrası işe dönme oranı \%11-69 arasında değişmektedir. ${ }^{[2]}$
Çalışmayla ilişkili olumlu faktörler ise; yaralanma öncesi yüksek eğitim düzeyi, yaralanma sonrası geçen süre, yaralanma yaşının küçük olması ve genç olma olarak belirtilmektedir. ${ }^{[4]}$ Ülkemizde OY'lerin çalışma oranı \%14-36 arasındadır; ilişkili bulunan faktörler ise benzerdir. ${ }^{[4,9]}$

\section{REHABILITASYON SÜRECINDE KARŞILAŞILAN SORUNLAR}

\section{Pulmoner Sistem}

Özellikle akut dönem olmak üzere OY sonrası solunum disfonksiyonu sık görülür; en sık atelektazi görülmektedir. Atelektazi ile birlikte pnömoni, plevral effüzyon, mekanik ventilatör gerektiren solunum yetmezliği ve pulmoner emboli OY'li hastalarda en sık mortaliteye neden olan komplikasyonlardır. ${ }^{[4,10]}$ Solunum disfonksiyonunun derecesi lezyonun seviyesi ve şiddeti ile ilgilidir. Yüksek servikal ve torakal lezyonlar en fazla riske sahiptir. C1-C4 seviyesindeki OY'de diyafram etkilendiği için mekanik ventilatör gereksinimi vardır. Daha aşağı seviyelerde ise yardımcı solunum kasları interkostal, aksesuvar ve abdominal kaslarda paralizi, parezi veya spastisite nedeni ile akciğer hacmi ve toraks kompliansı azalır. ${ }^{[4]}$

Solunum disfonksiyonuna bağlı komplikasyonları önlemede ilk basamak sekresyonların temizlenmesi ve atelektazinin tedavisidir. Sekresyonları atmak için yaygın olarak kullanılan teknikler yardımlı öksürük, perküsyon, titreşim, aspirasyon ve destekli postüral drenajdır. Ventilasyonu arttırmak için ise solunum kaslarını güçlendirme egzersizleri planlanmalıdır. ${ }^{[4]}$ Medikal tedavide, bol hidrasyon, bronkodilatörler ve mukolitikler önerilmektedir. ${ }^{[3,4]}$ 
Diyafram, frenik sinir, kombine interkostal ve unilateral diyafram pace teknikleri, hastaları ventilatörlerden ayırmak ve enfeksiyon, atelektazi ve solunum yetmezliği insidansını azaltmak için kullanılmaktadır. ${ }^{[4]}$

\section{Derin Ven Trombozu (DVT) ve Pulmoner Emboli (PE)}

OY'de nörolojik disfonksiyon, immobilizasyon ve hiperkoagülopati nedeni ile venöz tromboemboli riski yüksektir. Spinal travma sonrası \%8-25 arası sıklıkta görülür. Profilaksi için düşük doz unfraksiyone heparin, düşük molekül ağırlıklı heparin (DMAH), mekanik kompresyon önerilmektedir. Mekanik yöntemler olarak profilakside intermittan pnömotik kompresyon, elastik basınç çorapları, venöz ayak pompası ve nöromusküler elektrik stimülasyonu sayılabilir.[11] Profilaksi yapılmayan hastalarda derin ven trombozu (DVT) sıklığının \%50-80 olduğu, pulmoner embolinin (PE) ise \%5 insidansla üçüncü en sık mortalite nedeni olduğu saptanmıştır. DVT profilaksisine operasyon sonrası ilk 48 saat içinde başlanmalıdır. [12,13]

PE çoğu zaman bulgu vermez; en sık bulguları ise dispne ve göguüs ağrısıdır. Tanıda ventilasyon/perfüzyon sintigrafisi ve spiral bilgisayarlı tomografi (BT) önerilir. ${ }^{[3,4]}$

DVT profilaksisinde DMAH, unfraksiyone heparine göre daha etkin ve kanama yönünden daha güvenilir bulunmuştur. ${ }^{[14]}$ DMAH'ler içinde en çok araştırılan enoxiparin'dir. Enoxiparin'in etkin dozu ile ilgili kesin bir bilgi yoktur; günde iki kez 30 mg ile günde bir kez $40 \mathrm{mg}$ arasında fark gösterilememiştir. ${ }^{[15]}$ Bir başka DMAH olan dalteparin'in de (5000 U/gün) etkinlik ve güvenilirliği enoxiparin'e (30 mg günde $2 \mathrm{kez}$ ) benzer bulunmuştur. ${ }^{[4]}$

OY Klinik Pratik Kılavuzu Konsorsiyumu'nda motor inkomplet yaralanmalarda taburculuğa kadar, komplike olmayan komplet yaralanmalarda sekiz hafta boyunca DVT profilaksisi önerilmektedir. Alt ekstremite fraktürü, geçirilmiş tromboz, kanser, kalp yetmezliği, obezitesi olan ve 70 yaşın üzerindeki komplet yaralanmalarda ise 12 hafta profilaksi yapılır. ${ }^{[15]}$

Mekanik yöntemlerden pnömatik kompresyon botları, yaralanmanın ilk iki haftasında önerilmektedir; fakat yeterli kanıt yoktur. ${ }^{[4]}$ Profilaksi süresi, her hastanın hasar şiddet ve seviyesi, eşlik eden yaralanmalar ve medikal durum, kanama riski, fonksiyonel durum göz önüne alınarak kişiselleştirilmelidir. Motor komplet yaralanma (ASIA -American Spinal Injury AssociationBozukluk Skalası [ABS] A ve B), alt ekstremite fraktürleri, ileri yaş, geçirilmiş DVT, kanser ve obezite varsa profilaksi süresi uzatılabilir. ${ }^{[15]}$
OY'li hastalarda DVT tedavisine genellikle DMAH veya unfraksiyone heparin ile başlanır ve oral antikoagülan warfarin'le altı ay boyunca devam edilir. Yeterli antikoagülasyon profilaksisine rağmen DVT veya $P E$ olması halinde veya inferior vena kava veya iliak venlerde tromboemboli olanlarda, vena kava filtresi endikedir. ${ }^{[3,4]}$

\section{Otonom Sistem}

Son yıllarda OY sonrası otonom sistem değerlendirilmesine ayrı bir önem verilmiştir. ASIA ve International Spinal Cord Society (ISCoS)'nin kurduğu bir komite, otonom fonksiyonları değerlendirilme formu oluşturulmuş ve bu form Türkçe'ye çevrilmiştir. ${ }^{[16,17]}$ OY'ye bağlı ortostatik hipotansiyon, bradikardi, otonom disrefleksi ve ısı regülasyon bozuklukları ortaya çıkabilir. Ortostatik hipotansiyon $(\mathrm{OH})$ supin pozisyondan dik pozisyona gelindiğinde semptomlu veya semptomsuz sistolik kan basıncının $20 \mathrm{mmHg}$ veya diastolik kan basıncının $10 \mathrm{mmHg}$ ve daha fazla düşmesidir. ${ }^{[15]} \mathrm{OH}$, paraplejiklere göre tetraplejiklerde daha sıktır. Hastanın bulanık görme, sersemlik, baş dönmesi, yorgunluk, huzursuzluk ve dispne gibi bulguları olur. Tedavide elastik çorap, abdominal yastık, yeterli sıvı alımı, progresif olarak baş açısını arttırarak yatırma, eğilebilir masayla giderek dik pozisyona gelme önerilir; genellikle medikal tedavi gerekmez. Gerekirse tuz tabletleri, midodrin veya fludrokortizon önerilir. ${ }^{[4,16]}$

\section{Bradikardi}

Erken dönemde özellikle komplet yüksek tetraplejik hastalarda görülür. Genellikle ilk haftalardan sonra spinal şok sona erip sempatik tonus geri döndüğünde düzelir. Başlangıçta yakın takibe alınır ancak kalp atım hızı 40/dakikanın altına düşmedikçe tedavi gerekmez. ${ }^{[3]}$

\section{Otonom disrefleksi (OD)}

T6 ve üzerindeki OY'de, lezyon seviyesinin altından kaynaklanan, rahatsız edici olan veya olmayan herhangi bir uyarana cevap olarak gelişen, sistolik kan basıncında $20-40 \mathrm{mmHg}$ 'lik ani yükselme, terleme, pilo-ereksiyon, kızarıklık, baş ağrısı, görme bulanıklığı, nazal konjesyon ve sıkıntı hissiyle ortaya çıkan önemli bir klinik tablodur. ${ }^{[4]}$ OD görülme insidansı $\% 20-70$ arasında değişmektedir. Nadir olarak T10 seviyesine kadar görülebilir. Genellikle spinal şok döneminden sonra ortaya çıkar; sıklık ve şiddeti yaralanma şiddetiyle paralellik gösterir. ${ }^{[4]}$

Otonom disrefleksinin en sık nedeni mesane distansiyonu ve fekal tıkaçlardır. Daha az sıklıkla tırnak batması, bası yarası, akut batın, enfeksiyon, kırıklar, 
spastisite, sıkı ortez ve ateller, girişimsel işlemler (ürodinami, sistoskopi gibi) olayı başlatan neden olabilir. ${ }^{[4]}$

Riskli hastalarda hasta ve yakınları OD semptomları ve yapılması gerekenler hakkında bilgilendirilmeleri önemlidir; OD'nin önlenmesi için gerekli önlemler alınmalıdır. OD atağında ise hızlı tanı ile tetikleyen faktörlerin bulunup ortadan kaldırılması gerekir.

OD tedavisinde ilk adım hastanın yatar pozisyondan oturur pozisyona getirilmesi, vücudu sıkan giysi ve atellerin çıkarılması, mesane ve barsak kateterinde tıkanma, mesane distansiyonu, fekal tıkaç gibi nedenlerin gözden geçirilip ortadan kaldırılmasıdır. Kan basıncı sık aralıklarla kontrol edilmelidir. ${ }^{[4]}$ Bunlara rağmen sistolik kan basıncı 160-180 mmHg'nin üzerinde ise farmakolojik tedaviye başlanmalıdır. Nifedipin, hidralazin, prazosin, kaptopril ve transdermal nitrat önerilen seçeneklerdir. OY Klinik Kılavuz Konsorsiyumu (Clinical Practice Guideline by the Consortium for Spinal Cord Medicine)'na göre ideal farmakolojik tedaviyi belirleyecek randomize çalışma yoktur. ${ }^{[18]}$ Nifedipin ve nitratlar en sık kullanılan ilaçlardır; dilaltı 10 mg verilir. Ancak, hasta son 24 saatte sildenafil kullanmış ise kontrendikedir. ${ }^{[18]}$ Glutamat sentezini engelleyen gabapentin ve pregabalinin de OD üzerinde etkili olabileceği düşünülmektedir.

\section{Isı regülasyonu bozuklukları}

T6 seviyesi üzerindeki komplet yaralanmalı hastalarda daha sıklıkla ortaya çıkar. Bu hastalarda hipotalamus ile bağlantı kesildiğinden, vazomotor kontrol, gerektiğinde terleme veya titreme kaybolur. OY'li hastalar poikilotermiktir, yani vücut ısıları ortama göre değişir: sıcakta yükselir, soğukta düşer ${ }^{\left[{ }^{[18]}\right.}$ Bu nedenle, özellikle yüksek seviyeli OY'lilerde ortam ısısının kontrol edilmesi, uygun giysi seçilmesi ve sıcak ortamlarda ağır egzersizlerin yapılmaması önemlidir. ${ }^{[3]}$

\section{Kardiyovasküler Sistem}

Servikal ve yüksek torasik yaralanmalardan sonra genellikle kardiyovasküler sistem disfonksiyonu gelişir. Yaralanma sonrası lezyon seviyesinin altında refleks kaybı, duyusal ve motor kaybın olduğu, 4-12 hafta süren spinal şok dönemi yaşanır; sempatik aktivitenin azalmasıyla, bradikardi, hipotansiyon ve hipotermi kliniği oluşabilir.

Kronik dönemde nörolojik hasarın sonuçlarına ek olarak sigara, aktivite azlığı ve obezite OY'li hastalarda kardiyovasküler hastalık sıklığını arttırarak erken ölümlere neden olabilir. ${ }^{[19]}$ Ayrıca, kötü ve yüksek kalorili beslenme, immobilizasyonun kardiyoprotektif özellikli yüksek-dansiteli lipoprotein (HDL)'de düşmeye neden olduğu saptanmıştır. Bu hastalar kronik dönemde insülin rezistansı, obezite ve hipertansiyonu içeren kardiyometabolik sendrom açısından da takip edilmelidir. ${ }^{[20]}$

\section{Heterotopik Ossifikasyon (HO)}

Heterotopik ossifikasyon periferik eklem çevresindeki yumuşak dokuda ektopik lamellar kemik oluşumudur. Spinal kord hasarını takiben \%20-30 hastada görülür ve nörolojik heterotopik ossifikasyon (NHO) olarak adlandırılır. Santral nörolojik sistem lezyonu sonrası genelllikle iki hafta ila üç ay içinde ortaya çıkar. ${ }^{[21]}$

HO'nun nedeni tam olarak anlaşılamamıştır. Patofizyolojik olarak mezenkimal hücrelerin çoğalması ve osteoblastlara farklılaşması ile ekstrasellüler matriks meydana gelir. Aylar içinde bu matriks kalsifiye olur. ${ }^{[21]}$ Son yıllarda; komplet OY (ABS A), eş zamanlı torasik travma, spastisite, trakeostomi, pnömoni ve üriner sistem enfeksiyonları risk faktörleri olarak tanımlanmıştır. ${ }^{[22]}$ En sık kalça ekleminde olmak üzere azalan sıklıkta diz, omuz ve dirsekte görülür. Eklem çevresinde ısı artışı, ağrı olabilir. Eklem hareket açıklığında azalma ve ankiloz ile fonksiyonel disabiliteye, bulunduğu yere göre damar ve sinir basılarına neden olabilir. ${ }^{[21]}$ Ayırıcı tanıda DVT, enfeksiyon, travma, gelişmekte olan bası yarası akla gelmelidir. Tanıda, erken dönemde klinik, serum alkalen fosfataz yüksekliği ve 99 mTc difosfonat ile üç fazlı kemik sintigrafisinde tutulum yardımcı olur. Son zamanlarda ultrasonografi de ucuz, güvenilir ve kolay ulaşılabilir olması nedeni ile erken tanıda önerilmektedir. Serum kreatin fosfokinaz, sedimantasyon, C-reaktif protein (CRP) düzeyleri yükselebilir. Direkt grafide ise geç dönemde matür kemik oluşumu saptanabilir. ${ }^{[23]} \mathrm{HO}$ profilaksisinde non-streoid anti-inflamatuvar ilaçlar (NSAii), bifosfonatlar ve radyoterapi kullanılabilir. NSAii, progenitor hücrelerin osteojenik farklılaşmasını inhibe ederek etki gösterir. Yan etkilerinden dolayı, kâr/zarar oranına göre başlanmalıdır. Düşük doz radyoterapinin de profilakside etkili olduğu saptanmıştır. NSAii'nin kontrendike olduğu durumlarda radyoterapinin $\mathrm{HO}$ profilaksisinde tercih edilebileceği belirtilmektedir. ${ }^{[24]}$

$\mathrm{HO}$ tedavisinde ise bifosfonatlar, nazik germe egzersizleri önerilmektedir. Cerrahi tedavi, günlük yaşam aktivitelerini engelleyen eklem hareket kısıtlılığı, sinir veya damar basısı ve bası yarası varsa planlanmalıdır. Cerrahisi kanlıdır, tam olarak çıkarılması hedeflenmez, ancak psödoartroz oluşturarak eklem hareket açıklığını arttırmak hedeflenir. ${ }^{[3]}$

\section{Osteoporoz}

Akut OY'den sonra gelişen iskelet sistemine yüklenmenin azalması ile osteoblastik ve osteoklastik 
aktivitede artış görülür. Takip eden aylarda osteoblastik aktivitede derin bir depresyon ve trabeküler kemik osteoklastik aktivitesinde artış meydana gelir. ${ }^{[25]}$

Osteoporoz (OP), kırık riskini, sonuç olarak morbidite, mortalite ve sağlık harcamalarını da arttırır. Yapılan çalışmalarda akut OY sonrası distal femurda, ilk dört ayda \%27 ve 14 ayda \%32 kemik mineral yoğunluğunda (KMY) azalma bildirilmiştir. Yaralanma sonrası 3-8 yılda bu azalma daha az olmakla birlikte devam eder. ${ }^{[26]}$

Paraplejiklerde pelvis ve alt ekstremitede, tetraplejiklerde buna ilaveten üst ekstremitede de kayıp olur. OY osteoporozunda trabeküler kemik daha fazla etkilenir. En çok tutulan yerler distal femur ve proksimal tibianın metafizepifizindeki trabeküler alanlardır. Oturmaya bağlı yüklenmeden dolayı lomber vertebranın kemik kaybından korunduğu düşünülmektedir; lomber vertebra osteoporozu saptanırsa diğer OP nedenleri gözden geçirilmelidir. ${ }^{[4]}$

Dual energy $X$-ray absorptiometry (DXA), quantitative computed tomography (QCT), peripheral quantitative computed tomography ( $\mathrm{PQCT}$ ), ve manyetik rezonans (MR) görüntüleme, kullanılan KMY ölçüm metodlarıdır; en sık DXA ve QCT kullanılır. Omurilik yaralanmalarının çoğu, doruk kemik kitlesine ulaşma yaşına gelmeden meydana gelir. Bundan dolayı OY'lilerin kemik dansitometresinde $\mathrm{T}$ skoru yerine, benzer yaş, cinsiyet, kilo ve ırka sahip kişilerin normal değerlerinin standart deviyasyonu olan Z skorunun kullanılması önerilmektedir. ${ }^{[27]}$

Farmakolojik tedavi için ise kalsiyum, fosfat, D vitamini, bifosfonatlar ve denosumab önerilmektedir. ${ }^{[25]}$

OY'li hastalarda alt ekstremite kırık insidansı \%1-34 arasındadır. Kırık en sık distal femurun suprakondiler bölgesinde görülür. Minimal travmayla veya travma olmaksızın kırık meydana gelebilmektedir. Ağrı yoksa klinik daha siliktir. ${ }^{[3]}$ Ambule olmayan hastalar daha çok konservatif olarak tedavi edilir; ambule olanlarda ise geleneksel kırık tedavisi önerilir. ${ }^{[3]}$ Çoğu kırık konservatif olarak yumuşak, destekli splintlerle tedavi edilir. Bası yarası yönünden hasta izlenmelidir.

\section{Nörojenik Barsak Disfonksiyonu}

Nörojenik barsak disfonksiyonu, OY sonrası kolon motilitesinde ve/veya anorektal sfinkter fonksiyonunun kaybı olarak tanımlanabilir. Konus medullarisin üzerinde yaralanan hastalarda refleks (üst motor nöron tipi) barsak gelişir, yani barsak motilitesi ve anorektal sfinkter tonusunda artış olur. Konstipasyon ve fekal retansiyon görülür. Dışkının boşaltılması dijital uyarı veya irritan suppozituvar ile uyarılan refleks aktivite ile sağlanır. Konus ve kauda ekina lezyonlarında ise arefleks barsak (alt motor nöron tipi barsak) görülür. İntestinal peristaltizm kaybolmuştur; sadece miyenterik pleksus koordinasyonu ile dışkı yavaşça ilerletilir. Konstipasyon, dış anal sfinkter aktivite kaybı ve levator ani kasında güçsüzlük nedeni ile inkontinans görülebilir. ${ }^{44,28]}$

Hastaları fiziksel, duygusal ve sosyal olarak etkileyen ve sık görülen bir durumdur. Rehabilitasyon döneminde etkin bir barsak programı uygulanması ile kişinin yaşam kalitesi yükselecektir. Barsak programının amacı, konstipasyon ve dışkı kaçağını önleyerek düzenli dışkılama alışkanlığı kazandırmaktır. Hastalarda ilk yapılması gerekenler; hastanın yaralanma seviyesi, hastalık öncesi barsak alışkanlığı, oturma dengesinin değerlendirilip yeterli sıvı alımı sağlayan bir diyet ile barsak boşaltım programı başlanmasıdır. ${ }^{[4]}$ Diyette lif miktarının arttırılması, normal kişilerdekilerin tersine, barsak geçiş süresini uzatabileceğinden önerilmez. ${ }^{[28]}$ Kolonik motiliteyi arttıran dijital stimülasyon da bu programda yer alır. Daha yeni bir yöntem transanal irrigasyondur; hastalarda konstipasyon ve inkontinansı azalttı̆̆ bildirilmektedir. Deneysel aşamada olan nörostimülasyon ve nöromodülasyon uygulamalarının da barsak şikâyetlerini iyileştirdiği yönünde çalışmalar vardır. ${ }^{[28]}$

\section{Nörojen Mesane}

Primer işeme merkezi spinal kordun sakral 2-4 seviyesine denk gelir. L1 vertebra seviyesi üzerindeki yaralanmalarda işeme refleksinin kortikal inhibisyonu ve ponstaki işeme merkezinin sorumlu olduğu detrüsör sfinkter koordinasyonu ortadan kalkar. Hastada istemsiz detrüsör kontraksiyonu, aşırı aktif detrüsör $(A A D)$ ve detrüsör sfinkter dissinerjisi (DSD) görülür. Daha alt seviyelerdeki yaralanmalarda ise sakral işeme merkezi etkilenir; hastada arefleks detrüsör $(A D)$ veya hipoaktif detrüsör ortaya çıkar. ${ }^{[4,28]}$

OY sonrası mesane rehabilitasyonu mümkün olan en kısa sürede başlamalıdır. Hasta değerlendirmesinde sorgulama ve fizik muayeneden sonra altın standart laboratuvar tetkiki video-üro-dinamidir; bu tetkik için en uygun dönem spinal şoktan hemen sonraki dönemdir. Hastanın nöroürolojik değerlendirmesi tamamlandıktan sonra uygun mesane drenaj metodunu seçerken yaş, cinsiyet, komorbiditeler, yaralanma seviyesi, üst ekstremite fonksiyonu, spastisite, bakıcı yardımı gibi faktörleri değerlendirmek gerekir. ${ }^{[4]}$

Tedavide amaç düşük rezidü idrarla, düşük mesane basınçlarında depolama ve işemenin yapılması ve kontinansın sağlanmasıdır. Böylece, üst ve alt üriner sistemde oluşabilecek komplikasyonların önlenmesi ve kişinin tekrar topluma dönmesi hedeflenir. Temiz aralıklı 
kateterizasyon en çok önerilen boşaltma metodudur. [3] Diğer yaklaşımlar valsalva ve crede manevrası, ritmik suprapubik mesane perküsyonu gibi mesane refleksini tetikleyen metodlardır. Mesane basıncının yüksek ise oral tedavide en yaygın antikolinerjik ilaçlar ve mesane içi botilunum toksin A enjeksiyonu kullanılmaktadır. ${ }^{[29]}$

OY'li hastaların nörojen mesane yönünden ömür boyu takip edilmesi önerilir. Sık karşılaşılan komplikasyonlar üriner enfeksiyon, taş, hidronefroz ve refludur. ${ }^{[4]}$

\section{Seksüel Sorunlar ve Fertilite}

OY en sık 28-42 yaş aralığında görülür. Psikolojik ve fizyolojik nedenlerden dolayı, seksüel disfonksiyon sık karşılaşılan bir sorundur. ${ }^{[30]}$ Erkeklerde psikojenik ereksiyon, kadınlarda lubrikasyon sempatik ve parasempatik sinir sistemi ile ilgilidir ve T11-L2 dermatomlarda duyu korunması ile ilişkilidir. Refleks ereksiyon ve vajinal vazokonjesyon ise parasempatik sistem kontrolündedir ve sakral refleksin korunması ile ilişkilidir. Hastanın değerlendirmesinde bulbokavernöz refleks (BKR) yararlıdır; hiperaktif BKR olan hastalarda refleks ereksiyon ve lubrikasyon genellikle mevcuttur. BKR hipoaktif ve S4-S5 dermatomlarında korunma varsa refleks ereksiyon ve lubrikasyon genellikle mümkündür; eğer BKR yoksa ve S4-S5 dermatomlarında duyu korunmamışsa T11 ve L2'de duyusal korunmaya bağlı psikojenik ereksiyon ve lubrikasyon beklenir. ${ }^{[3]}$

Seksüel sorunlar ile ilgili en fazla araştırılan konu erektil disfonksiyondur. Sıklıkla birinci sıra tedavi olarak kullanılan 5-fosfodiesteraz inhibitörleri, OY sonrası erektil disfonksiyon tedavisinde etkin bulunmuştur. ${ }^{[4]}$ Kullanılan diğer yöntemler vakum cihazları, penil enjeksiyonlar ve penil implanttır. ${ }^{[30]}$

OY sonrası erkeklerin \%90'dan fazlasında semen kalitesi bozulur ve infertilite ortaya çıkar. ${ }^{[30]}$ OY'li kadınlarda menstrüel siklus geçici olarak kesintiye uğrar: gebelik oranı \%14'tür. ${ }^{[4,30]}$ T10 seviyesinin üzerindeki kadınlarda doğumun başladığının hissedilemeyeceği ve T6 seviyesi üzerindeki hastalarda doğumda OD sıklığının artacağı akılda tutulmalıdır.

\section{Bası Yarası}

OY'li hastalarda \%30-60 oranında görülür. Sık görüldüğü, hastanın yaşam kalitesini bozup morbidite ve mortaliteyi arttırdığı için önemlidir. En sık sakrum, iskium, trokanterler ve topuklarda gelişir. ${ }^{[31]}$ Bası yarası ile ilişkili faktörlerin araştırıldığı çalışmamızda bu faktörler; tetraplejik ve komplet lezyonlar, günlük ambulasyon süresi, rehabilitasyona geç başlama, idrar ve gaita inkontinansı, vücut kitle indeksi ve albümin düzeyinin düşüklügü olarak belirlenmiştir. ${ }^{[4]}$
Bası yarası açısından en önemli yaklaşım oluşumunu önlemektir. Bu açıdan bası yarası riskinin belirlenmesi, günlük cilt kontrolünün yapılması ve basınç kaldırma tekniklerinin (minder, yastık ve bacak koruyucuları) uygulanması ilk basamaktır. Hasta ve yakınlarının eğitimi yanında sağlık çalışanlarının da bu konuda farkındalık ve bilgi düzeyi çok önemlidir. ${ }^{[4,31]}$

Bası yaralarının değerlendirme ve sınıflamasında en sık Amerika'daki Ulusal Bası Yarası Danışma Heyeti'nin geliştirdiği sınıflama kullanııır. ${ }^{[4]}$ Bası yarasının tedavisinde öncelikle bölgenin üzerinden basınç kaldırılır, beslenme düzenlenir, uygun temizlik ve debridman uygulanır. Konservatif yöntemler ile kısa zamanda kapanmayacak ileri evre bası yaralarında cerrahi tedavi uygundur.

\section{Spastisite}

OY'li hastalarda ilk 6-12 ay içinde \%70 oranında spastisite gelişmektedir. Psikolojik, sosyal, ekonomik durum ve yaşam kalitesini olumsuz etkileyerek erken mortaliteye neden olabilir. ${ }^{[32]}$ Spastisite servikal ve üst torakal yaralanmalarda daha sık görülürken, $A B S B$ ve C'de, ABS A ve D'ye göre daha şiddetli görülür. [33]

Tedavide ilk basamak, önlenebilir faktörleri ortadan kaldırmaktır. Spastisiteyi arttıran nosiseptif ve ekstraseptif uyarıların varlığı; örneğin enfeksiyon, konstipasyon, bası yarası, tırnak batması vb. sorgulanmalıdır ve eğer varsa bunlara yönelik gerekli tedaviler uygulanmalıdır. Spastisite tedavisi; farmakolojik olmayan, farmakolojik ve cerrahi tedavi olarak gruplandırılabilir. Fizik tedavi uygulamaları ve rehabilitasyon teknikleri farmakolojik olmayan tedavi grubunu oluşturur. Omurilik yaralanması sonrasında görülen spastisitenin oral medikal tedavisinde ve fleksör spazmlarda baklofenin etkili olduğu gözlenmiştir. ${ }^{[33,34]}$ Sedasyon, sersemlik, halsizlik, konfüzyon, mide bulantısı, kabızlık, hipotoni, ataksi, parestezi, delirium ve konvülziyon gibi yan etkileri olabilir. Özellikle ağrılı gece spazmı ve gece artan spastisite tedavisinde diazepam ve diğer benzodiazepinler kullanılır. Diğer bir ajan olan dantrolen sodyum, periferik etkili, kognitif yan etkileri daha az olan bir antispastik ajandır. OY'ye bağlı görülen spastisitede kullanımı sınırlıdır. Eğer omurilik yaralanmasına kognitif bozukluk eşlik ediyorsa (örneğin travmatik beyin yaralanması ve OY birlikteliğinde) ilk seçilecek ajan olabilir. ${ }^{[33]}$ Hepatotoksisite en önemli yan etkisidir. Tizanidinin omurilik yaralanmalı hastalarda kas tonusunda ve spazm sıklığında anlamlı azalmaya yol açtığı gösterilmiştir. Spastisite birkaç kas grubunu etkiliyorsa (fokal ya da multifokal) lokal tedavi denenebilir. Lokal anestezikler, alkol, fenol, botulinum toksini lokal tedavide kullanılan ajanlardır. ${ }^{[33]}$ 
Şiddetli yaygın spastisite tedavisinde bu yöntemler ile sonuç alınamadığında diğer bir seçenek intratekal uygulamadır; en sık baklofen kullanılır. İntratekal uygulanan baklofenin, oral baklofenin \%1 dozunda aynı klinik etkinliği sağladığı gösterilmiştir.

\section{Ağrı}

OY sonrası hastaların yaklaşık 2/3'ünde görülen ağrı, yaşam kalitesini bozan ve rehabilitasyona katılımını etkileyen en önemli semptomlardan biridir. ${ }^{[35]}$ Ağrı nosiseptif (kas iskelet sistemi ağrısı ve viseral ağrı) ve nöropatik ağrı (lezyon seviyesinde ve lezyon altında) olarak ikiye ayrılır. ${ }^{[35]}$ Nosiseptif ağrının tedavisinde; kas-iskelet sisteminin aşırı ve yanlış kullanmanın önlenmesi, basit analjezikler, NSAii, opioidler, lokal enjeksiyonlar, EHA ve güçlendirme egzersizleri ve fizik tedavi modaliteleri (buz, transkutanöz elektrik stimülasyon (TENS) vb.) kullanılır. ${ }^{[4,35]}$ OY'li hastaların \%53'ünde nöropatik ağrı görülür. Nöropatik ağrının tedavisinde ise yine buz, sıcak, TENS gibi fizik tedavi modalitelerin yanı sıra egzersiz, psikososyal biofeedback, basit analjezikler, NSAii, gabapentin, pregabalin, trisiklik antidepresanlar, hafif opiodler ve opioidler kullanılabilir. ${ }^{[3,35]}$ Bu tedavilerle de cevap alınamıyorsa, cerrahi tedaviler (DREZ -dorsal root entry zone, dorsal kolon stimulatörü) gündeme gelir. ${ }^{[3,35]}$

\section{Tetraplejik El ve Üst Ekstremite}

Tetraplejik hastalarda el ve kol fonksiyonlarının iyileşme önceliğinin yürüme, mesane, barsak ve seksüel fonksiyonlarından daha yüksek olduğu rapor edilmiştir. ${ }^{[36]}$ Yeni yaralanmış bir hastada üst ekstremitenin değerlendirilmesi ilk 48 saat içinde yapılmalıdır ve üst ekstremiteyi korumaya yönelik önlemler alınmalıdır. ${ }^{[37]}$ OY'den sonraki 0-6 haftalık dönemde ödemin önlenmesi, eklemlerin görünüm, hareket açıklığı ve fonksiyonelliğinin korunması önemlidir. ${ }^{[38]}$ ASIA sınıflamasına göre motor C5 ve C6 seviyeli hastalarda önkolda fleksiyon ve supinasyon kontraktürü gelişimi en sık rastlanan sorunlardan biridir. Bu hastalarda önkolu ekstansiyon ve pronasyonda pozisyonlamak önemlidir. C7 seviyesindeki yaralanmalarda el bilek ve parmakların, C8 yaralanmalarında ise metakarpofarengeal eklemlerin hiperekstansiyonu engellenmelidir. ${ }^{[38]}$

Omuz kuşağındaki en proksimal kaslardan elin interensek kaslarına kadar tüm kas güçleri, el kavrama gücü, sıkıştırma (pinch) gücü, lateral kavrama, üç nokta tutuşu ve parmak ucu tutuşu değerlendirilir. ${ }^{[38]}$ Başparmak pulpasından bakılan iki nokta ayıım testinin tetraplejik el değerlendirmesinde önemi büyüktür. İki nokta ayrımının $10 \mathrm{~mm}$ veya daha az olması kutanöz kontrolün yeterli olduğunu gösterir, $10 \mathrm{~mm}$ üzerinde olması ise elin fonksiyon kontrolünde göz yardımının gerekli olduğunu gösterir. ${ }^{[38]}$ Fonksiyonel değerlendirmede hastanın günlük yaşam aktivitelerinde elini nasıl, ne derece kullandığı ya da kullanamadığı kaydedilir.

Tetraplejik el için uluslararası bir sınıflama oluşturulmuştur. $^{[38]}$ Genellikle OY'den $6-9$ ay sonra nörolojik iyileşme plato düzeyine ulaştığı zaman, tetraplejik hastalar için üst ekstremitede cerrahi tedavi düşünülebileceği bildirilse de her hastanın medikal ve psikolojik durumu, sosyal desteği, hedefleri, operasyon sonrası rehabilitasyon imkânı ekip tarafından değerlendirilerek uygun zaman belirlenmelidir. ${ }^{[38]}$ Rekonstrüksiyon ile genelde hastaların ASIA motor seviyesi bir veya iki seviye yükselir. Tetraplejik üst ekstremite cerrahisinde uygulanan yöntemler; tendon transferleri, tenodezler ve artrodezlerdir. Cerrahi sonrası rehabilitasyon programı, immobilizasyon, ödem tedavisi, skar tedavisi, mobilizasyon, fonksiyonel beceri eğitimi ve güçlendirme olmak üzere altı ana başık altında toplanabilir. ${ }^{[38]}$

\section{OY SONRASI BESLENME}

OY'li hastalar başlangıçta spinal şok, kilo kaybı, malnütrisyona neden olan katabolik süreç içindedirler. Uzun dönemde katabolizma hızında artış, nitrojen kaybı ve hipermetabolizma gözlenir; vücut kompozisyonlarında bozulma, kaslarda atrofi, yağ kitlesinde rölatif artış, enerji, glikoz, lipid ve vitamin metabolizmalarında değişiklik, sempatik sinir sistem aktivitesinde azalma ve hastanın hareketliliğinde kısıtlılık olur. ${ }^{[4]}$ Gastrik boşalmada gecikme, intestinal geçiş süresinde uzama ve kolonik motilitenin azalması beklenir. Bütün bunların sonucunda kilo alımı, kardiyovasküler hastalık (KVH) riskinde artma, insülin direnci ve osteoporoz görülebilir. Kronik dönemde obezite önemli bir sorun olabilir. Bası yaraları, nörojen mesane ve nörojen barsak OY'li hastada beslenme ile ilişkilendirilebilecek diğer komplikasyonlardır. ${ }^{[4]}$

OY'li hastaların günlük enerji gereksinimleri sağlıklı bireylerden daha düşüktür. Bu hastalarda, sağlıklı kişiler için geliştirilmiş ideal kilo çizelgeleri \%10-15 azaltılarak kullanılabilir. ${ }^{[4]}$

\section{OMURILIK YARALANMASINDA PROGNOZ}

OY'li hastalarda fonksiyonel iyileşmeyi en iyi gösteren, yaralanmadan 72 saat sonra yapilan ilk muayenedeki nörolojik durumdur. Bu muayeneden sonra $A B S$ $A$, komplet yaralanma olarak değerlendirilen hastanın \%80 ABS A olarak devam ettiği, \%10 ABS B, \%10 ABS C'ye ilerleyebildiği bildirilmektedir. ${ }^{[39]}$ 
Travmatik OY'nin erken dönemde iyileşme potansiyelini gösteren önemli faktörler; ilk yaralanma seviyesi, başlangıç kas gücü ve yaralanmanın komplet ya da inkomplet olmasıdır. ${ }^{[4]}$ Ayrıca yaş, cinsiyet, yaralanmanın şiddeti ve etiyolojisi iyileşme prognozunu belirlemede etkilidir [28]. Lateral kortikospinal yolların anatomik olarak lateral spinotalamik yollara yakın komşuluğu nedeniyle, iğne batırma duyusunun korunmuş olması önemli bir motor iyileşme belirtecidir. ${ }^{[4,39]}$

Bazı yazarlar, akut yaralanmadan sonra spinal şoka giren hastaların, spinal şok görülmeyenlere göre daha kötü prognoza sahip olduğunu söylerler. Yaralanmadan hemen sonra ilk çıkan refleks gecikmiş plantar reflekstir. ${ }^{[4]}$ Gecikmiş plantar refleks ile komplet yaralanma ve alt ekstremitenin motor iyileşmesinin kötü olması arasında yüksek oranda korelasyon bulunmuştur. Bulbokavernöz refleksin yokluğu alt motor nöron lezyonunu gösterir, ki bu da özellikle mesane, barsak ve seksüel fonksiyonlar için önemlidir. ${ }^{[4]}$

Komplet tetraplejik hastaların çoğunda (\%66-90) yaralanmadan sonraki ilk haftadan bir yıla kadar geçen sürede motor seviyede, bir seviye düzelme olur. Üst ekstremitedeki iyileşme en çok ilk 3-6 ay içinde görülür. Motor ve duysal komplet tetraplejikler genellikle fonksiyonel ambulatuvar olamazlar. ${ }^{[4]}$ Inkomplet tetraplejikler komplet tetraplejiklere göre göreceli olarak daha iyi bir prognoza sahiptir; üst ekstremite iyileşmesi kompletlere göre iki kat fazladır.

Komplet paraplejiklerin motor iyileşmesi başlangıç nörolojik yaralanma seviyesine göre değişir. Nörolojik yaralanma seviyesini üçe ayırabiliriz: T8 ve üzeri, T9T11 arası, T12 ve altı. T8 ve üzeri komplet paraplejiklerin alt ekstremitesinde hiçbir motor kazanım olmaz. T9-T11 arası hastaların sadece \%15'inde ilk yılda kalça fleksörlerinde veya diz ekstansörlerinde 3/5'in altında bir motor kazanım olur. Ambulasyon potansiyeli en iyi olan hasta grubu inkomplet paraplejiklerdir. ${ }^{[4]}$

\section{İnomplet Sendromlar}

Santral kord sendromlu hastaların ambulasyon potansiyeli yüksektir, fakat yaştan etkilenerek \%40-97 arası değişkenlik gösterebilir. ${ }^{[4,39]}$ İnkomplet sendromlar içinde Brown-Sequard Sendromu \%75'lik bir oranla en iyi ambulasyon potansiyeline sahip sendromdur. Anterior kord sendromuysa \%10-20 gibi düşük bir ambulatuvar iyileşme oranına sahiptir. ${ }^{[39]}$

\section{PEDIATRIK OY}

Çocukluk döneminde OY daha az görülür. Adolesanlarda yetişkinlerde olduğu gibi erkek/ kız oranı 4:1'dir. ${ }^{[40]}$ Infantlarda C1-C3 seviyesinde, adolesanlarda C4-C8 seviyesinde yaralanma daha sıktır. En sık rastlanan etiyolojik nedenler; taşıt kazası $(\% 40,6)$, yüksekten düşme $(\% 34)$, suya dalma $(\% 10,4)$ ve silahlı yaralanmadır $(\% 9,4)$. Pediatrik OY'liler için ayrı bir değerlendirme sistemi olmayıp ISNCSCI (International Standards for Neurological Classification of Spinal Cord Injury) kullanılmaktadır. ISNCSCl'nın önerdiği muayene beş yaş üstü için uygundur. ${ }^{[4,40]}$

Pediatrik OY rehabilitasyonu erişkinlere göre farklılık gösterir. İmmatür kas iskelet sistemi nedeni ile skolyoz, eklem subluksasyonu ve dislokasyonu gibi ciddi ortopedik problemler yaşanabilir. ${ }^{[0]}$ Çocuk ve adolesanlarda rehabilitasyon prensipleri ve hedefleri büyüme ve gelişmeye paralel olarak değişmelidir; rehabilitasyon aile merkezli olmalıdır.

\section{OMURILIK YARALANMASI SONRASI TAKIP}

Genel tıp, acil tıbbı ve rehabilitasyon tıbbında gelişmeler ile OY'li bireylerin de hayatta kalma oranları artmış ve yaşam süreleri uzamıştır. ${ }^{[41]}$ OY'li hastada medikal değişiklikleri saptamak, nörolojik muayenedeki değişiklikleri izlemek, gelişebilecek komplikasyonları önlemek, oluştuğunda tanı koymak ve tedavi etmek, verilen cihazları kontrol etmek, gerektiğinde yeni cihazlar reçete etmek, hastaların yaşam kalitelerini arttırmak, topluma katılımını sağlamak, tedavi maliyetlerini düşürmek için düzenli takip yapılması gerekir. ${ }^{[42]}$ OY'li hastalara taburculukları sonrasında bu konuda deneyimli bir ekip tarafından takip önerilmektedir; bu takiplerin içerik ve sıklığı konusunda kılavuzlar yoktur. Hastanın taburculuk sonrasında ilk takibi üç ay sonra; ardından ilk iki yıl hastanın durumuna göre 3-6 ay aralıklar ile, iki yıldan sonra stabil hastalarda yılda bir kez olarak önerilir. OY'li bireylerin takibi için öneriler aşağıda gözden geçirilmiştir ${ }^{[42]}$ :

\section{Günlük Takip}

OY'li hasta her gün bası yarası açısından cilt kontrolü yapmalıdır.

\section{Aylık Takip}

OY'li kişi, her birey gibi kendine her ay; kadın ise meme, erkek ise testis muayenesi yapmalıdır.

\section{Yıllık Takip}

Sağlıklı kişiler ve OY'li bireyler; yıllık genel sağlık kontrolü, gaitada gizli kan, 40 yaş üzeri kadınlar mamografi, 55 yaş üzerinde ise ayrıntılı göz muayenesi, 75 yaşından itibaren erkeklerde PSA (prostat spesifik antijen) ve dijital rektal muayene ile değerlendirilmelidir. Kişilere en az 2-3 yılda bir tam kan sayımı, biyokimya 
testleri yanında kadınlara meme muayenesi, jinekolojik değerlendirme ve smear yapılmalıdır.

OY'li bireylerde bunlara ek olarak kilo ve kan basıncı kontrolü, torakal sekiz ve üzeri seviyedeki hastalar için grip aşısı yapılmalıdır. Hastalar ilk beş yılda yıllık, daha sonra en az 2-3 yılda bir anamnez ve tam fizik muayene (ISNCSCI değerlendirmesi, eklem hareket açıklığı, kontraktür, fonksiyonel durum, vb.), ürolojik sistem, postür, ortez ve cihazlar, tam cilt değerlendirmesi yönünden takip edilmelidir.

\section{Beş Yıllık Takip}

Sağlıklı kişilerde 35 yaşından sonra lipid profili, 50 yaşından sonra sigmoidoskopi ve BT kolonografi tetkikleri; OY'li bireylerde ise ek olarak solunum fonksiyon testi yapılması ve yaşam şeklindeki değişikliklerinin gözden geçirilmesi önerilir.

\section{On Yıllık Takip}

Sağlıklı kişilerde tetanoz aşı rapeli ve kolonoskopi; bunlara ek olarak torakal sekiz ve üzeri seviyedeki hastalar için pnömokok aşısı önerilir.

\section{KAYNAKLAR}

1. Mekki M, Delgado AD, Fry A, Putrino D, Huang V. Robotic Rehabilitation and Spinal Cord Injury: a Narrative Review. Neurotherapeutics 2018;15(3):604-17. Crossref

2. Karacan I, Koyuncu H, Pekel Ö, Sümbüloğlu G, Kırnap M, Dursun H, Kalkan A, Cengiz A, Yalınkıliç A, Ünalan H, Nas K, Orkun S, Tekeoğlu i. Traumatic spinal cord injuries in Turkey: a nation-wide epidemiological study. Spinal Cord 2000;38(11):697-701. Crossref

3. Bryce T. Spinal Cord Injury. In: Cifu DX, editor. Braddom's Physical Medicine and Rehabilitation, 5th ed. Philadelphia: Saunders; 2016. pp.1095-136.

4. Erhan B, Gündüz B. Omurilik yaralanması. İçinde: Oğuz H, Çakırbay H, Yanık B, editörler. Tıbbi Rehabilitasyon. İstanbul: Nobel Kitabevi; 2015. pp.461-78.

5. Best KL, Arbour-Nicitopoulos KP, Sweet SN. Communitybased physical activity and wheelchair mobility programs for individuals with spinal cord injury in Canada: Current reflections and future directions. J Spinal Cord Med 2017;40(6):777-82. Crossref

6. Fehlings MG, Tetreault LA, Aarabi B, Anderson P, Arnold PM, Brodke DS, Chiba K, Dettori JR, Furlan JC, Harrop JS, Hawryluk G, Holly LT, Howley S, Jeji T, Ryan SK, Kotter M, Kurpad S, Kwon BK, Marino RJ, Martin AR, Massicotte E, Merli G, Middleton JW, Nakashima $\mathrm{H}$, Nagoshi N, Palmieri K, Singh A, Skelly AC, Tsai EC, Vaccaro A, Wilson JR, Yee A, Burns AS. A clinical practice guideline for the management of patients with acute spinal cord injury: recommendations on the type and timing of rehabilitation. Global Spine J 2017;7(3 Suppl):231S-8S. Crossref

7. Arora T, Oates A, Lynd K, Musselman KE. Current state of balance assessment during transferring, sitting, standing and walking activities for the spinal cord injured population: A systematic review. J Spinal Cord Med 2018:1-14. Crossref
8. Moreno A, Zidarov D, Raju C, BoruffJ, Ahmed S. Integrating the perspectives of individuals with spinal cord injuries, their family caregivers and healthcare professionals from the time of rehabilitation admission to community reintegration: protocol for a scoping study on $\mathrm{SCl}$ needs. BMJ Open 2017;7(8):e014331. Crossref

9. Yavuzer G, Ergin S. Productivity of patients with spinal cord injury in Turkey. Int J Rehabil Res 2002;25(2):153-5. Crossref

10. Savic G, DeVivo M, Frankel H, Jamous M, Soni B, Charlifue S. Causes of death after traumatic spinal cord injury -a 70-year British study. Spinal Cord 2017;55(10):891-7. Crossref

11. Chen HL, Wang XD. Heparin for venous thromboembolism prophylaxis in patients with acute spinal cord injury: a systematic review and meta-analysis. Spinal Cord 2013;51(8):596-602. Crossref

12. Zeeshan M, Khan M, O'Keeffe T, Pollack N, Hamidi M, Kulvatunyou N, Sakran JV, Gries L, Joseph B. Optimal timing of initiation of thromboprophylaxis in spine trauma managed operatively: A nationwide propensity-matched analysis of trauma quality improvement program. J Trauma Acute Care Surg 2018;85(2):387-92. Crossref

13. Arnold PM, Harrop JS, Merli G, Tetreault LG, Kwon BK, Casha S, Palmieri K, Wilson JR, Fehlings MG, Holmer HK, Norvell DC. Efficacy, Safety, and Timing of Anticoagulant Thromboprophylaxis for the Prevention of Venous Thromboembolism in Patients With Acute Spinal Cord Injury: A Systematic Review. Global Spine J 2017;7(3 Suppl):138S50S. Crossref

14. Teasell RW, Hsieh JT, Aubut J-AL, Eng JJ, Krassioukov A, Tu L; Spinal Cord Injury Rehabilitation Evidence Review Research Team. Venous thromboembolism after spinal cord injury. Arch Phys Med Rehabil 2009;90(2):232-45. Crossref

15. Prevention of Venous Thromboembolism in Individuals with Spinal Cord Injury: Clinical Practice Guidelines for Health Care Providers, 3rd ed.: Consortium for Spinal Cord Medicine. Top Spinal Cord Inj Rehabil 2016;22(3):209-40. Crossref

16. Krassioukov A, Biering-Sørensen F, Donovan W, Kennelly M, Kirshblum S, Krogh K, Alexander MS, Vogel L, Wecht J. International standards to document remaining autonomic function after spinal cord injury. J Spinal Cord Med 2012;35(4):201-10. Crossref

17. Gündüz B. Omurilik Yaralanması için Otonom Standartlar Değerlendirme Formu. Turk J Phys Med Rehabil 2012;58 Suppl 1; 38-41. Crossref

18. Campagnolo D, Merli G. Autonomic and cardiovascular complications of spinal cord injury. In: Kirshblum S, Campagnolo D, DeLisa J, editors. Spinal Cord Medicine. Philadelphia, PA: Lippincott/Williams \& Wilkins; 2002. pp.123-34.

19. Tom VJ, Partida E, Mironets E, Hou S. Cardiovascular dysfunction following spinal cord injury. Neural Regen Res 2016;11(2):189. Crossref

20. Frontera JE, Mollett P. Aging with Spinal Cord Injury: An Update. Phys Med Rehabil Clin N Am 2017;28(4):821-8. Crossref

21. Genêt F, Ruet A, Almangour W, Gatin L, Denormandie P, Schnitzler A. Beliefs relating to recurrence of heterotopic ossification following excision in patients with spinal cord injury: a review. Spinal Cord 2015;53(5):340-4. Crossref

22. Müseler A, Grasmücke $D$, Jansen $O$, Aach $M$, Meindl $R$, Schildhauer T, Citak M. In-hospital outcomes following single-dose radiation therapy in the treatment of heterotopic ossification of the hip following spinal cord injury-an analysis of 444 cases. Spinal Cord 2017;55(3):244-6. Crossref 
23. Teasell RW, Mehta S, Aubut J, Ashe MC, Sequeira K, Macaluso S, Tu L; SCIRE Research Team. A systematic review of the therapeutic interventions for heterotopic ossification after spinal cord injury. Spinal Cord 2010;48(7):512-21. Crossref

24. Ranganathan K, Loder S, Agarwal S, Wong WW, Forsberg J, Davis TA, Wang S, James AW, Levi B. Heterotopic ossification: basic-science principles and clinical correlates. J Bone Joint Surg 2015;97(13):1101-11. Crossref

25. Bauman WA, Cardozo CP. Osteoporosis in individuals with spinal cord injury. PM\&R 2015;7(2):188-201. Crossref

26. Cirnigliaro C, Myslinski M, La Fountaine M, Kirshblum S, Forrest G, Bauman W. Bone loss at the distal femur and proximal tibia in persons with spinal cord injury: imaging approaches, risk of fracture, and potential treatment options. Osteoporos Int 2017;28(3):747-65. Crossref

27. Dionyssiotis Y. Spinal cord injury-related bone impairment and fractures: an update on epidemiology and physiopathological mechanisms. J Musculoskelet Neuronal Interact 2011;11(3):257-65.

28. Stoffel JT, Van der Aa F, Wittmann D, Yande S, Elliott S. Neurogenic bowel management for the adult spinal cord injury patient. World J Urol 2018;36(10):1587-92. Crossref

29. Romo PGB, Smith CP, Cox A, Averbeck MA, Dowling C, Beckford C, Manohar P, Duran S, Cameron AP. Non-surgical urologic management of neurogenic bladder after spinal cord injury. World J Urol 201836(10):1555-68. Crossref

30. Alexander MS, Aisen CM, Alexander SM, Aisen ML. Sexual concerns after Spinal Cord Injury: An update on management. NeuroRehabilitation 2017;41(2):343-57. Crossref

31. Atkinson RA, Cullum NA. Interventions for pressure ulcers: a summary of evidence for prevention and treatment. Spinal Cord 2018;56(3):186-98. Crossref

32. McKay WB, Sweatman WM, Field-Fote EC. The experience of spasticity after spinal cord injury: perceived characteristics and impact on daily life. Spinal Cord 2018;56(5):478-86. Crossref
33. Erhan B, Gündüz B. Spastisite. In: Oğuz H, editor. Tıbbi Rehabilitasyon. İstanbul: Nobel Kitabevi; 2015. pp.565-73.

34. Palazón-García R, Alcobendas-Maestro M, Esclarin-de Ruz A, Benavente-Valdepeñas AM. Treatment of spasticity in spinal cord injury with botulinum toxin. J Spinal Cord Med 2018:17. Crossref

35. Shiao R, Lee-Kubli CA. Neuropathic Pain After Spinal Cord Injury: Challenges and Research Perspectives. Neurotherapeutics 2018;15(3):635-53. Crossref

36. Dunn JA, Sinnott KA, Rothwell AG, Mohammed KD, Simcock JW. Tendon transfer surgery for people with tetraplegia: an overview. Arch Phys Med Rehabil 2016;97(6 Suppl):S75-80. Crossref

37. Erhan B, Alp M. Serebral paralizi, inme, travmatik beyin hasarı ve tetrapleji. İçinde: Çerezci Ö, Ataker Y, Canbulat N, Güdemez E, editörler. El Rehabilitasyonu. İstanbul: Amerikan Hastanesi Yayınları, Eramedya; 2013. pp.303-19.

38. Erhan B, Gündüz B. Omurga-omurilik travmalarında klinik muayene ve sınıflama. İçinde: Hancı M, Erhan B, editörler. Omurga ve Omurilik Yaralanmalar. Antalya: Intertıp Kitapevi; 2012. pp.207-20.

39. Scivoletto G, Tamburella F, Laurenza L, Torre M, Molinari $\mathrm{M}$. Who is going to walk? A review of the factors influencing walking recovery after spinal cord injury. Front Hum Neurosci 2014;8. Crossref

40. Powell A, Davidson L. Pediatric spinal cord injury: a review by organ system. Phys Med Rehabil Clin N Am 2015;26(1):10932. Crossref

41. Charlifue $S$, Jha A, Lammertse D. Aging with spinal cord injury. Phys Med Rehabil Clin N Am 2010;21(2):383-402. Crossref

42. Erhan B. Medulla Spinalis Yaralanmalı Hastalarda Geç Dönem Takip Protokolü. Turk J Phys Med Rehabilitation 2006;52(Suppl B);818-20. 